\title{
Rights may conflict with assisted-dying ruling
}

$\mathrm{T}$

he Supreme Court of Canada's decision to overturn the law prohibiting physician-assisted dying throws the conflict between patients' and doctors' rights squarely into the political arena.

The unanimous decision by all nine Supreme Court justices on Feb. 6, 2015, upheld an earlier ruling by a British Columbia judge who determined that laws outlawing physician-assisted dying contravene the Canadian Charter of Rights and Freedoms. The Supreme Court justices accepted the argument that Criminal Code of Canada provisions prevent competent adults from making decisions about their "bodily integrity and medical care." Banning physician-assisted dying, the justices ruled, results in a "cruel" choice that could leave people to endure intolerable suffering, infringing on their rights to liberty and security as guaranteed under section 7 of the charter.

The justices made clear that nothing in the decision, Carter v. Canada, compels doctors to provide assistance in dying.

The Supreme Court suspended its decision for one year, giving Parliament and/or provincial legislatures that time to pass new laws. The ruling means the debate about how to regulate physicianassisted dying, or whether federal or provincial governments should use the notwithstanding clause to opt out of the charter provisions, will now rage among politicians and voters. Physician-assisted dying could become a critical issue in the upcoming federal election. Until other laws are passed, it is still technically illegal for doctors to assist in dying.

The Supreme Court factum acknowledged that physicians' associations and regulatory colleges will become central players in influencing any new legislation. The justices also addressed the issue of physicians who conscientiously object to assisting patients in dying by making an explicit comparison to an earlier decision involving Dr. Henry Morgentaler that struck down the ban on abortion.

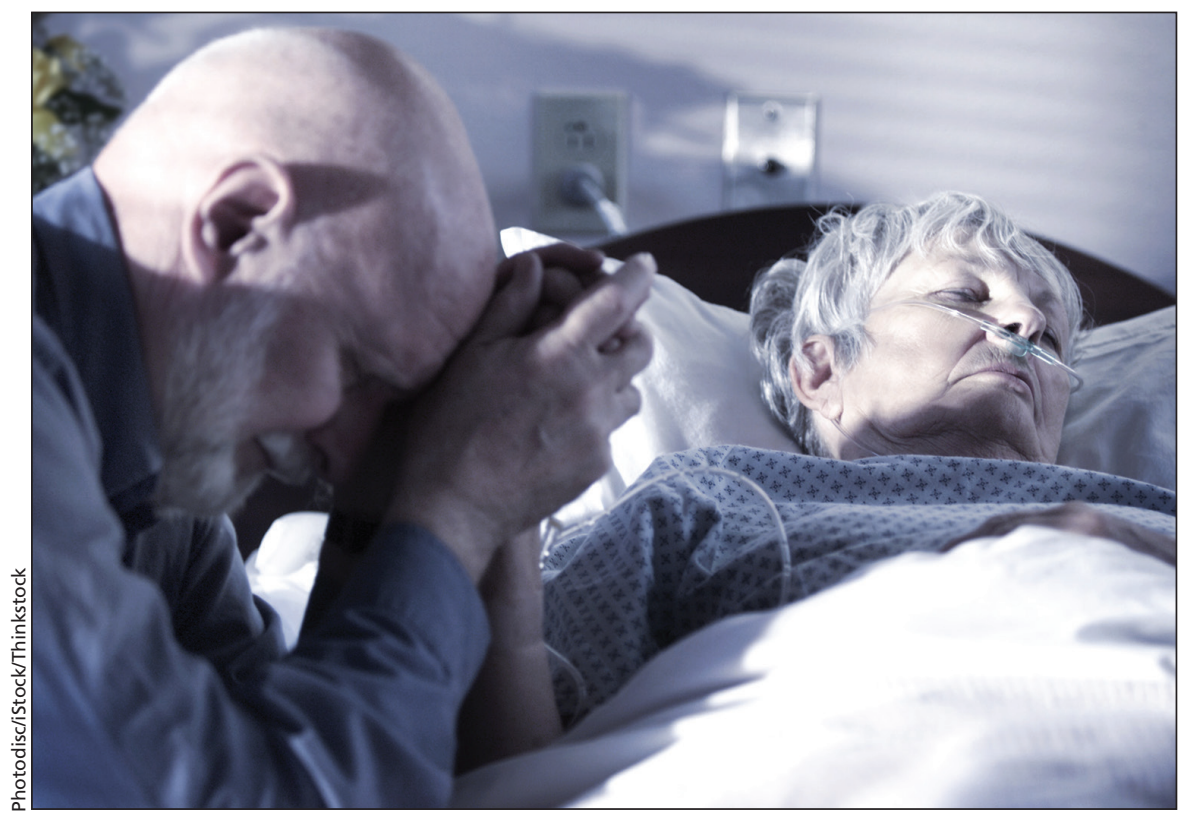

Federal and provincial governments have a year to pass new laws on physician-assisted dying.

"We note - as did Beetz J. in addressing the topic of physician participation in abortion in $R$. v. Morgentaler - that a physician's decision to participate in assisted dying is a matter of conscience and, in some cases, of religious belief," the justices wrote. "In making this observation, we do not wish to preempt the legislative and regulatory response to this judgment. Rather, we underline that the charter rights of patients and physicians will need to be reconciled."

The Canadian Medical Association (CMA) wants to work with parliamentarians to draft the new legislation and ensure that patients' needs are met while physicians maintain the right to follow their conscience, the organization stated in a news release.

For close to two years, the association has been studying medical aid to dying as it is regulated in Europe and in five US states, Dr. Chris Simpson, the CMA president, said in an interview. The CMA has also held town hall meetings across Canada to canvas the feelings of the general public and doctors. "We'd like to bring that expertise and reflect what we heard to the table, so that we can come up with a system that meticulously protects vulnerable people but one that provides access to medical aid in dying for those who need it," Simpson said.

There is no consensus among CMA's 80000 members on the issue of whether physicians should provide medical aid to the dying, says Simpson, but a resolution that leaves the matter to a doctor's individual conscience passed overwhelmingly at the association's General Council meeting in August, 2014.

As the Supreme Court noted, creating laws, regulations and practice guidelines that reconcile patients' and doctors' rights will be critical, Simpson says. "The core of that reconciliation will be that we respect individual doctors' rights to conscientiously object."

"That's in patients' best interests. Ultimately, no patient is going to want their physician pulled in against their will to help them with such a profound issue."

Some doctors welcomed the decision, including Dr. James Downar, a palliative care physician at Toronto's 
University Health Network who wrote a CMAJ Commentary on physicianassisted death in 2014.

"It's a vindication for people who have decided there are types of suffering that can only be relieved by death," Downar said an interview. Although palliative care remains an option for some people and governments must fund it more fully, there are too-few palliative care beds across Canada and it will never be an option for everyone, he added.

Downar said it is critical that legislators involve stakeholders in crafting a process to ensure all Canadians have access to physicians who will assist them in dying if they meet prescribed conditions. Any process must also require doctors who have a conscientious objection to refer patients to a colleague who will medically assist them with dying. That will be a challenge, he knows. "We need to recognize that there are parts of Canada where physician availability is not high."

Downar believes the rest of Canada can learn from Quebec, which passed a comprehensive act concerning end-oflife care that permits physician-assisted dying under strict conditions. In addition, Canadian legislators should take heed of the US states and European countries like the Netherlands that allow doctors to hasten the end of life. "Finally, we can move beyond the yesno debate into the practical," he added.

Other palliative-care physicians, however, are deeply concerned that the Supreme Court decision will negatively affect their relationship with their patients. They want any new practice guidelines or legislation to preserve their current role.

"Our role is that we don't hasten the end of life, but we allow people to live as fully as they can before they die," says Dr. Jessica Simon, a palliative care physician in Calgary, Alta. "The intentional act of ending someone's life is not part of palliative medicine. I've never had a case where someone has had to die in order to relieve their suffering, because we have other tools at our disposal, including palliative sedation."

Although Simon says she has "no conscientious objection" to people taking their own lives, she has "a deep concern that it should not be seen as a medical act."

"I do not look forward to the day when I come home and someone says 'What did you do at work today?' and I say 'Today I killed somebody'," Simon says.

Canada's Minister of Justice Peter MacKay said the Conservative government will take its time in introducing any new legislation - even as he acknowledged the federal election is a consideration, though "not the primary consideration" in the timing of any new bill. "The most important part of what Parliament will do is how we protect all Canadians' rights and interests in this particular case," he told reporters. Laura Eggertson, Ottawa, Ont.

CMAJ 2015. DOI:10.1503/cmaj.109-4994 